\title{
Urban theology endeavours and a theological vision of hope and justice for post-apartheid South African cities
}

\author{
James, Geneviève \\ University of South Africa \\ jamesgl@unisa.ac.za
}

\begin{abstract}
Twenty one years since the dawn of democracy in South Africa, the cities of the nation appear to be in a downward spiral of injustice and callousness. This article considers the transformative significance of urban theology. Beginning with a description of the author's insertion into the administrative capital of South Africa the article proceeds to chart out urban theology as a "God and Bible", "contextual", "intellectual" and "activist" endeavour. It then illuminates the vision of the New Jerusalem as described in the Old Testament in Isaiah 65:17-24 juxtaposing it with the context of South African cities today. This ancient urban vision will serve as a theological mandate for urban transformation.
\end{abstract}

Keywords

Urban theology, Isaiah 65, post-apartheid cities

\section{Capital Punishment: My entry into the City of Tshwane}

No amount of literary exposure could have prepared me for my relocation to the executive administrative capital city of Tshwane (Pretoria) ${ }^{1}$ on account of a new job at the University of South Africa. I moved into a tiny apartment on Schoeman Street, now known as Frances Baard ${ }^{2}$ ) in a part

1 There is ongoing confusion and debate over the name of the city. Originally named Pretoria after a Voortrekker leader, the new government calls the metropolitan area Tshwane. See Pre-History of Pretoria.

2 The city embarked on a name change process that led to the change of 27 street names in the Pretoria central business district. The name changes were to be more representative of South Africa's multicultural history and were to reflect "shared heritage". Frances Baard was "an organiser of the ANC Women's League that was a defendant in the 
of the city called Arcadia. The street in which I lived was literally a stone's throw away from the Union Buildings which is the seat of the Presidency of the Republic of South Africa.

Having surveyed the area on a map I had great expectations for my new neighbourhood. My apartment complex was located opposite the Pretoria Arts Museum, close to the Union Buildings, a few kilometres from the student district of Hatfield and a number of foreign embassies. The city lays claim to having the largest number of embassies after Washington $\mathrm{DC}^{3}$. Naturally I was looking forward to living in a part of the city that showed great promise for cosmopolitan urban living, at least, that's how it appeared on the map.

On arrival I encountered a rather different scene than the one I conjured in my mind. The neighbourhood I moved into had become part of the city's red light district. This was home to a unique amalgam of sex workers, university students, young professionals and admin workers. In addition to this, foreign migrants from across the African continent increasingly became a feature in the neighbourhood. Plying their trade in bedding, clothing and wall mirrors (I bought my mirror from an Egyptian), the migrant communities' steely resolve to progress economically and their boundless resilience became essential character traits in an urban environment seething with suspicion, envy and anger. Sadly migrant communities were often the targets of malicious assault and even murder, as xenophobia became a South African psychosis of note.

Back at my apartment block chaos became the order of the day (and night). I lived in apartment 107 and on either side of me I was flanked by a drug addicted couple in apartment 108 and young sex workers in apartment 106. The drug addicted couple were prone to violent rage which they usually acted out towards each other around midnight. Meanwhile the sex workers' clients sometimes knocked on my door by mistake. I noticed that their clients were always professionally dressed, they appeared to be financially well off, the cars they drove were always high-end luxury models. One day,

Treason Trial and later became a member of the executive committee of the South African Congress of Trade Unions". See Pretoria's new street names.

3 See Africa Unusual: 15 facts and figures from around the continent to make you smile - or laugh. Mail \& Guardian Africa. 
one of the women from apartment 106 told me about how her drug dealer/ pimp had severely beaten her. When she threatened to report him to the police, he responded that he would personally take her to the police station since he was by no means intimidated by the South African police, who, he added, were "all in his pocket" due to the routine bribes he was paying them.

Amidst all the human drama I also noticed that the buildings around the area were poorly maintained and began to take on a derelict appearance. Unsafe, unhealthy and dilapidated buildings became havens for the homeless, while criminals also took the opportunity to set up camp to conduct their clandestine activities. The parks where no longer spaces for children and families, now colonised by jobless men and shifty drug dealers these spaces became no-go areas especially at night. It was also plain to see the expansive wealth gap in this city. I would often see the homeless at the food market using up coins which they received from appeals to motorists at traffic lights. I soon realised how expensive it was to buy a single food item as opposed to a bulk pack that a regular suburban household would purchase.

The whirlwind of disorientation I observed in my neighbourhood represented a microcosm of the wider challenges of the capital city. At the dawn of the $21^{\text {st }}$ century scholars Cameron and Krynauw (2001:1) prepared a revealing urban study for the newly elected Councillors of the City of Tshwane. The two described Tshwane as "a divided city" (:26) and suggested that, "City of Tshwane: A Tale of Two Cities" (:1) could be an appropriate sub-theme of their study. The polarization of the city is attributed primarily to the affluence of the southern part of city while residence of the northern part are relegated to second class status both in terms of access to opportunity, which is categorized as work, education, health, recreation and access to housing, transport and housing subsidies (:26). The polarization described by Cameron and Krynauw stems from apartheid legacy (:26) where white communities where generally well served and affluent while high density black communities in the north such as Mamelodi, Atteridgeville, Garankuwa and Soshanguve were underserved and distressed. South African missiologist Mashau (2014:196) describes these communities as "symbols of apartheid, created for blacks who were used as cheap labourers in the white-run economy." 
On a recent tour to a lucrative diamond mine in Cullinan ${ }^{4}$ north of the city, a tour guide made a comment that if the mine's sludge dam would break, the community of Mamalodi at the foot of the mining hills will be flooded. It was so ironic to stand on land rich with diamonds while the people of the community below lived in abject poverty. One extraordinary theologian, the late Nico Smith who was a professor, priest and political activist took up residence in the community of Mamalodi during the height of apartheid. Smith and his wife were at the time, the only white people allowed to stay in a black township. Compelled by his faith and stirred by the injustice of apartheid Smith explained, "I knew I had to make a choice," he said. "I would have to decide to teach my theology but not apply it, or apply it and take the consequences" (Hevesi 2010). ${ }^{5}$

As I began to process the literary reflections on urban theology against the backdrop of my new city I became more inclined towards action. My increased agency was stimulated by both scholars who have reflected on the city and faith, as well as, the city itself which begged to tell its own stories through the streets, architecture, people, places and spaces. Inspired by theologians like Professor Nico Smith, I too began to think that the theology I was teaching needed action. I began to explore the need for an urban theological vision, one rooted in biblical and theological reflection and a careful understanding of context that would give rise to action.

\section{Capital disillusionment}

My new home, the City of Tshwane, the great administrative capital, should have benefitted from its chief status as the seat of the presidency, and not just any presidency, the new South African presidency commencing with the inaugural of the iconic freedom fighter Nelson Mandela, the presidency that comprised of the nation's liberators from the captivity of diabolical racial oppression and injustice. One would have expected to discover a

4 The Cullinan Diamond Mine yielded the rough diamond from which The Great Star of Africa diamond which is displayed in England's royal sceptre and The Lessor Star of Africa which forms part of the British Imperial State Crown. This mine continues to remain a major diamond producer over a hundred years since its establishment.

5 See Saayman, W 2013.Troublemaker in Israel: Nico Smith and the struggle for justice in apartheid South Africa. 
city of shalom; a city reclaimed from the ravages of ethnocentrism, social, economic and political injustice, a city on the path to restoration, wholeness and integrity. This city should have been an exemplar of a capital city that triumphed over apartheid malevolence and cruelty and now provides the impetus for transformation for other South African cities, yet, to my disillusionment, this was not the case.

April 2015 marked twenty one years since South Africa became a democratic country, yet, the lived experiences in the capital city, particularly for the disenfranchised, revealed little signs of triumph over injustice, rather a compelling manifestation of the condemnation of the poor, exploitation of the vulnerable, exclusion and contempt of the foreigner, racial and ethnic division, rampant corruption and an ever-widening wealth gap. Instead of discovering city of gratitude, humility and compassion, I discovered a city of hubris, plainly dispassionate about the needs of the homeless, hungry, sick and dying and lacking in a sense of urgency to do what is right.

\section{Urban theological endeavours}

My experiences in the city have given me ample opportunity to observe the elements that I explore in this article. As a young theologian I often wondered what value theology, particularly urban theology, had for the complex context I lived in. This led me to pursue my $\mathrm{PhD}$ studies in the field of urban theology $y^{6}$ I tried to understand what would be the prerequisites of doing theology in the context of the city. There are many models for doing theology; perhaps the most uncomplicated yet beneficial is Holland and Henriot's (1983) "pastoral cycle" containing four elements: experience, social analysis, theological reflection, and pastoral action. The two make a distinction between an academic approach which is study from distance and a pastoral approach which is direct involvement study. The pastoral cycle has since given birth to numerous iterations. ${ }^{7}$ Two of which, have been most notable to me: firstly missiologist JNJ (Klippies) Kritzinger's (2011:32-

6 See James, GL. 2007. And God said "Let there be Charismatics in the City: A Study into the Practise and Presence of a Charismatic Megachurch in the City of Durban". UKZN. Parts of this article are drawn from this study.

7 For one such iteration see Karecki's Teaching missiology in context: Adaptations of the pastoral circle'. 
59) analytical framework which contains an elaborate and comprehensive seven element praxis matrix and secondly Laurie Green's (2009) "Let's do theology" which is an exceptional contribution to the discourse on theological method. For the purpose of this paper, I gain inspiration from the pastoral cycle to highlight four primary endeavours (four serious and sincere efforts) of urban theology. These are: urban theology as a God and Bible endeavour, and as a contextual, intellectual and activist endeavour. These endeavours must not be seen as separate efforts, instead they are best embarked on in conjunction with each other, supporting, nourishing and giving life to the other.

\subsection{Urban theology as a God and Bible endeavour}

Is God present and active in the city? Is God speaking in the city and if so how and where do we hear the voice of God and where do we witness the acts of God? How does one determine the voice and call of God in the context of the city? Is God present in secularized western cities or is God present in the excessively religious cities of the majority world? What is the significance of the life and work of Jesus for our cities? Has God completely vacated the city? For some, urban theology (or any theology for that matter) is useless, irrelevant and delusional. It is a study of the non-existent and as such, it is a fool's expedition, the exploratory trajectories of the neurotic,

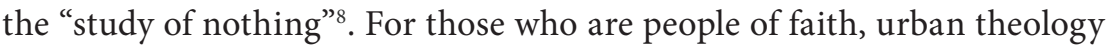
is simply obligatory in an undeniably urban world, with insurmountable challenges that the disciplines of sociology, urban planning and even economics, cannot in isolation deliver from captivity of injustice, greed and ethnocentrism. This became evident when, not even the Ivy League economists could have protected the world from the global economic crisis and its lingering devastation. Human nature is prone to hubris and as such cannot support sustained transformation, therefore urban theology is a God and Bible endeavour since God promises a transformed city through God's divine interventions and renewing power and also shows us the ethos and praxis by which we will realize this transformation.

8 See The Guardian's What is theology? http://www.theguardian.com/commentisfree/belief/2010/ may/24/religion-philosophy 
Against this backdrop a critical entry point into urban theology would be to read the Bible with urban lens as encouraged by seminal urban theology publications by Ray Bakke in A Theology as big as the City (1997) and Urban Christian (1987), Harvie Conn and Manuel Ortiz (2001) in Urban Ministry, The Kingdom, The City and the People of God, and Robert Linthicum's City of God, City of Satan: A Biblical Theology of the Urban City (1991). These publications encourage reflection on biblical texts to determine a message of restoration, mercy and justice in the context of urban injustice and hopelessness. As the clock edged closer to the dawning of the $21^{\text {st }}$ century, a time when there was no shortage of doom's day and end-of-time theories, these scholars challenged Christians to overcome their urban pessimism by accepting the ultimate mandate, a biblical mandate to "seek the shalom of the city" (Jeremiah 29). Urban theologians encouraged the Church, Christians in general and mission movements to open their eyes and see the city like it has never seen it before, as a place where God loves, rejoices, cries, lives and works. Through a perusal of the Old and New Testaments these scholars harvested a wealth of explicit and implicit texts that dealt with God's love for the city, God's vision for the city and the salvation destiny culminating in the city. These theologians called for greater sensitivity to injustice and malevolence in the city as well as greater discernment of the signs of faith, hope, love and restoration, reconciliation and revitalization.

While embarking on a careful reflection of Biblical texts related to the city, both the lamentations and joys of the urban condition as reflected in the Old and New Testaments, it is also necessary to read the city against the backdrop of key theological themes of salvation, mercy, justice, redemption, restoration and belonging to the family of God. So while scholars call for reading the Bible with urban eyes it is also necessary to read the urban with theological eyes. Reading the city with theological eyes requires reflecting on all layers of the urban context whether it be urban planning, water and food security, the provision of housing and health care, or the environmental challenges of the city. A theological message can be ascertained for all of these challenges since God does not remain estranged by our physical challenges, instead, through the incarnation of Jesus Christ, we see God's commitment to be present with us amidst the complicity of our existence. As Bosch eloquently wrote, 
"...the incarnate Christ, the human Jesus of Nazareth who wearily trod the dusty roads of Palestine where he took compassion on those who were marginalized. He is also the one who suffers in the favelas of Brazil and with the discarded people in South Africa's resettlement areas" (Bosch 1991).

\subsection{Urban theology as a contextual endeavour}

Socrates: "I'm a lover of learning, and trees and open country won't teach me anything, whereas men [children and women] in the city do." Plato, Phaedrus, 230d

From its categorization it is clear that urban theology is a contextual endeavour. Amidst the plethora of urban disciplines seeking the well-being and development of the city, urban theology holds claim to a particular distinction. Urban theology is concerned with doing theology in the particular geographical and spatial context of the urban. Since the world is now an urban world with the majority of its people living in urban areas, urban theology holds weighty significance for our contemporary lives. The city as a centre of dominance and control cannot be underestimated because whatever happens in the city has a direct influence on the surrounding areas. In 1938 Wirth (in Le Gates and Stout 1996:189-197) argues that there are three key characteristics of cities: large populations, size and social heterogeneity. Wirth developed the concept of "urbanism" as a way of life and it is helpful to quote him at length due to his relevance to our contemporary age.

The degree to which the contemporary world may be said to be "urban" is not fully or accurately measured by the proportion of the total population living in cities. The influences which cities exert on the social life of man (sic) are greater than the ratio of the urban population would indicate, for the city is not only increasingly the dwelling place and the workshop of modern man (sic), but is the initiating and controlling Center of economic, political and cultural life that has drawn the most remote communities of the world into its orbit and woven diverse areas, peoples and activities into a cosmos (Wirth 1938:342). 
More recently commenting on the dominance of the city in the $21^{\text {st }}$ century, Khana (2011) explains how cities have risen to power over the power of the state,

In this century, it will be the city-not the state-that becomes the nexus of economic and political power. Already, the world's most important cities generate their own wealth and shape national politics as much as the reverse. The rise of global hubs in Asia is a much more important factor in the rebalancing of global power between West and East than the growth of Asian military power, which has been much slower. In terms of economic might, consider that just forty city-regions are responsible for over two-thirds of the total world economy and most of its innovation. To fuel further growth, an estimated $\$ 53$ trillion will be invested in urban infrastructure in the coming two decades.

In Africa urbanization took place much later than other continents, yet Africans experienced the fastest pace of urbanization with severe and unparalleled urban challenges and crisis (Hove et al 2013). According to the African Development Bank, "Africa has experienced the highest urban growth during the last two decades at $3.5 \%$ per year and this rate of growth is expected to hold into 2050"'.

In South Africa rapid urbanisation has led to an unprecedented shift of rural dwellers to urban areas, and as such caused great strain on public utilities and severe and unrelenting social discontent. Since the collapse of the apartheid system and the abolition of pass laws, influx control, and the Group Areas Act, South African cities have undergone radical structural, demographic, cultural, and socio-economic changes (de Beer 1998:52 -55). Despite being twenty one years into democracy the legacy of apartheid continues to impinge on South African urban realities.

In the light of these urban dynamics, urban theology as a theology of place and space seeks to discern the significance of the Christian message of hope, faith, salvation and renewal in the complexity and creativity of the contemporary context of the city. The city is a meaningful setting to explore

9 See Urbanization in Africa http://www.afdb.org/en/blogs/afdb-championing-inclusive-growthacross-africa/post/urbanization-in-africa-10143/ 
the assertions of the Gospel, as such; urban theologians are concerned with the consciousness, discourse and action that underscores the redemptive and emancipatory presence of God. Further to this, place is intrinsically linked to faith and identity formation.

Bakke $(1987,1997)$ offers what he calls a "Theology of place". He criticizes the church for its lack of understanding concerning the importance of place or location. He views the discarding of city locations in order to resettle in 'safe' environments regrettable. Bakke asserts that "places can be sacred" by virtue of the fact that God is present and interested, in the urban environment, and calls us to the city, making it a holy place (1987:62). He further describes "God's kingdom agenda" as seeking "the personal salvation of all persons and the social transformation of all places..." (Bakke1997:66). For Bakke (1981:62), theology is "God in dialogue with his people in all their thousands of different environments". Theology always proceeds from a location. "It's within a particular context and experience that theological reflection takes place and is moulded into shape" (Duffield 1997:17). Theology therefore cannot be devoid of a situation, context or location. Since the dominating context of this age is urban, theology must take this shift into consideration.

The task of the urban theologian is to read, interpret and gain deeper understanding of the context against the backdrop of the Biblical text for the purpose of transformation. It demands rigorous thinking around theological issues that arise in urban communities. The Faithful Cities Report (2006:49) rightly suggests that, "Congregations and their leaders need an accurate understanding of the changing context in which they operate - and the impact of social and economic change on their mission".

\subsection{Urban theology as an intellectual endeavour}

Civic culture was born, in ancient Athens and Jerusalem, when intellectuals took their stand in public spaces, and took it on themselves to act as the consciousness and conscience of their cities (Berman 1987:423)."

Urban Theology is an intellectual endeavour involving deep thinking, urban and theological reflection, rigorous engagement with scholars and 
thought leaders for the goal of designing and implementing transformative activities.

Thoughtless action in the urban context can have devastating consequences. I have yet to see how actions such as marching around the city with placards stating "God hates sinners" or the ominous, "Turn or Burn" can possibly benefit the city. One can have the desire and urgency to take action to address the challenges or even the sins of the city; however, if these actions are without critical thought and careful consideration then they may produce undesirable results. One cannot address urban needs by passionate intensity alone. For this reason urban theology necessitates some thinking effort.

Elshtain (2014) denounces the cultural pressure to always "do" explaining that such a culture evades the responsibility to think. She explains, "Things move much too fast. The role for public intellectuals today is to bestir the quiet voice of ethically engaged reason". Writing about Christian ministry, the editor of the journal of The London Urban Theology Project elucidates the hazards of action only, "The point is that in active ministry no one is asking you to write and to reflect. Therefore thoughts remain half-formed, half-baked, and underdeveloped". Further to this, the intellectual task of urban theology should be to consider the city as a space of critical thinking or as Strauss (2005) suggests "a space of critical reception, rather than doctrinaire assimilation”. For Vincent (in Duffield 1997:18) urban theology "is no casual reflecting on the Christian tradition, but rather a radical call from God to reflect with the people in the midst of decay and despair upon the realities of the situation and what the gospel says to it".

According to Chomsky (1967) the responsibility of intellectuals includes "the creation and analysis of ideology". Furedi (2005:163) sees the role of the intellectual as giving "voice to the uncomfortable questions that contemporary society seeks to avoid". Despite living in what is being described as a knowledge society we are ironically antagonistic towards use of the intellect. Furedi (2005:157) describes this as "the inexorable tendency towards the dumbing down of public life". Anti-intellectualism or what is being described as "philistinism" which is a social attitude that 
prioritises materialism and despises intellectual pursuits" 10 is endemic and bordering on pathological, in our urban centres.

The problem on the African continent is that centuries of western intellectual hegemony has left us with the dangerous dependence on thought leaders and theologians in western countries. Elsewhere Baijnath and I (2014) discussed the asymmetries in development thought,

The dominance of the western canon in knowledge production and dissemination most often signifies that in the African context we are under the perpetual tutelage of the west as our discourse, development research, knowledge pursuits and social justice aspirations are all structured and formed along western modes of thinking.

When we abdicate our role as thinkers and intellectuals we become content with others doing the thinking for us. In addition to this, due to the scale and intensity of our social challenges, our time, is often spend on action without the accompanying deep critical thought. Consequently there is a great need to develop a thriving African urban theology intellectual community. The Institute for Urban Ministry hosted by the Tshwane Leadership Foundation has been successful at gathering thinkers and activists from across the continent to discuss urban theology from an African perspective. Stephan De Beer, a South African scholar that continues to shape urban theological discourse and consciousness can be read in the following publications, "Whose knowledges shape our city? Advancing a community-based urban praxis "(De Beer 2014), "Urban South Africa: an opportunity for liberating theological education" (De Beer 2012), “Towards a fusion of horizons: thematic contours for an urban public theological praxis-agenda in South Africa" (De Beer and Swart 2014).

Urban theology demands rigour, depth, richness and quality of thought. The absence of thought, study, and reflection could potentially lead to disorder, dysfunction and possibly chaos. If we fail to think carefully about urban theology our urban action may become reactionary, it may appear more as shock responses to urban challenges. Thinking must encourage the critique of motives, power dynamics and the worldview and ideological

10 See Merriam-Webster's definition of philistinism. 
framework of the thinker. Thinking in the context of urban ministry produces decisive benefits for constructive positive action.

\subsection{Urban theology as an activist endeavour}

Now while I have strongly advocated for the benefits of thinking in the urban theological endeavour there will always be the danger of analysisparalysis or the risk of straying into an ideological rut if thinking is not accompanied by transformative action. In the sixties Chomsky (1967) commented on the deficiency of intellectuals in the west. He explained that western intellectuals have,

lost interest in converting ideas into social levers for the radical transformation of society. Now that we have achieved the pluralistic society of the Welfare State, they see no further need for a radical transformation of society; we may tinker with our way of life here and there, but it would be wrong to try to modify it in any significant way.

According to Hannah Arendt (1950) in the "Human Condition", Western philosophy too often has focused on the contemplative life (vita contemplativa) and has neglected the active life (vita activa). Intellectual reflection without transformative action becomes empty and irrelevant. When considering urban theology, the Faithful Cities Report offers a helpful perspective, "It makes no sense to claim that theology is primarily or exclusively expressed in doctrinal statements or academic treatises. On the contrary, we understand that these propositions are derived from the incarnational principles already enacted and embodied". (Faithful Cities 2006:14) Robert Schreiter (1985:17) summed it best, "Theology is more than words it is a pedagogical process liberating consciousness and inciting action".

Now that I have discussed these critical endeavours of urban theology, I will proceed to explore a biblical text located in the Old Testament book of Isaiah chapter 65 verses 17-24. I will consider this text as an exercise in reading the Bible with urban eyes and in reading the city against the backdrop of theological themes in order to develop transformative action. 


\section{Isaiah 65: A compelling vision of urban hope and justice for post-apartheid cities}

17 "See, I will create new heavens and a new earth.

The former things will not be remembered, nor will they come to mind.

${ }^{18}$ But be glad and rejoice forever in what I will create, for I will create Jerusalem to be a delight and its people a joy.

${ }^{19}$ I will rejoice over Jerusalem and take delight in my people; the sound of weeping and of crying will be heard in it no more.

20 "Never again will there be in it an infant who lives but a few days, or an old man who does not live out his years; the one who dies at a hundred will be thought a mere child; the one who fails to reach[a] a hundred will be considered accursed.

${ }^{21}$ They will build houses and dwell in them; they will plant vineyards and eat their fruit.

${ }^{22}$ No longer will they build houses and others live in them, or plant and others eat. For as the days of a tree, so will be the days of my people; my chosen ones will long enjoy the work of their hands.

${ }^{23}$ They will not labor in vain, nor will they bear children doomed to misfortune; for they will be a people blessed by the Lord, they and their descendants with them.

${ }^{24}$ Before they call I will answer; while they are still speaking I will hear.

The text above has been considered by both Bakke (1987) and Linthicum (1991) as a compelling theological vision for the city. Brueggemann (1993:77) describes the city of Jerusalem as a model city of "urban crisis and urban possibility". Bakke describes Isaiah 65 as containing "a blueprint for a redeemed city" (Bakke: 1987).

The text may be perceived as a utopian text and as such appears as a pipedream or a pleasant aberration. There are many examples of utopian literature since ancient and classic antiquity times accompanied by ample 
criticism of utopian visions. Do we abandon alternative visions of a restored, just world, or do we explore these visions as a possible tool for $21^{\text {st }}$ century urban renewal? It is my argument that urban visions of hope and justice are essential and should not be shunned on account of appearing utopian. The much citied Proverbs 29 verse 18 explicitly warns of the consequence of the lack of vision, "Where there is no vision the people perish" still conveys a great truth. When our cities appear at their vilest, an urban vision of restoration and beauty becomes simply indispensable.

Kovacs (2007) comments on the seemingly idealistic overtones of Isaiah 65,

We might say Isaiah's grand vision here is only idealism or wishful thinking. We're not sure how any of this is going to be fulfilled and there's plenty in this text completely mocked by our present circumstances. But it's not about us; it's about the new, unexpected thing God will do...

Reflecting on the work of Brueggemann, Kovacs (2007) continues to explain the value of hope in the current age of suspicion and scepticism, "When promise is banished and circumstances govern...we are most likely left with nothing but despair." In the absence of a compelling vision, urban despair will surely settle in.

For Brueggemann the book of Isaiah is about the city of Jerusalem. He asserts that Isaiah 65 has "close and intentional ties to Isaiah 1:21-26. Isaiah 65 is the afterward reflected in Isaiah in chapter one" (Brueggemann 1993:78). He charts the flow of the book, beginning with its initial harshness toward the city (chapter 1), shifting to tenderness towards the city (chapter 40), and ends with the ultimate hope for the city (chapters 65-66). ${ }^{11} \mathrm{He}(: 77)$ sums up the book as follows:-

- "The city as intended by God is for faithfulness, justice, and righteousness, for social relations and structures that work for the good of all; in other words; it is a place of rightly deployed resources.

11 See Laing Lectures 2008: Walter Brueggemann (3 of 3) http://elliotritzema.com/2008/10/12/ laing-lectures-2008-walter-brueggemann-3-of-3/ 
- But the city runs amok, becomes a whore, forsaking justice and righteousness, and then comes murder and bribes, disregard of widows and orphans. This sorry state... leads to suffering, displacement and exile.

- A third season of the city yet to come "Afterward you shall be called the city of righteousness, the faithful city..."

It is my position, that the South African context of the City of Tshwane I described in the introduction of this article parallels the city of Jerusalem as represented in Isaiah, and summed up by Brueggemann above. I do not assume the capacity to treat this text with the rigour of an expert biblical scholar. What I will attempt to do in the following section of this article is to reflect (with other scholars) on the significant themes present in this text against the backdrop of the South African urban reality.

\section{Isaiah 65: verses 17-19}

Bakke (1997:82) refers to opening verses as the call for "public celebrations and happiness". The city and God are united in a common joy. If God is in the city there is still sufficient reason to be hopeful and joyful. The task of the church is to permeate the urban environment with the Christian joyfulness and hope.

Verses 17-19 are abundantly clear about who will initiate the renewal of the city. Throughout these verses the creator God takes personal initiative for the reorder and redemption of the city, establishing joy as one of its hallmarks. According to Brueggemann the 'I will create' refers to "God's management of the creation resources. God will pre-empt our failed management ... with an act of magisterial administration..." (Brueggemann1993:80). In the context of South African cities, management of resources have led to a major deficit of joy. The sounds of weeping and crying continue to be heard in our cities due to a social order that is crafted to dehumanize and vex the poor and vulnerable while the rich and powerful are rewarded, given preferential treatment and idolized. A South African trade unionist evocatively described the situation,

"If we look at lots of our cities, they are all surrounded by a ring of fire. We have seen in almost every direction around Johannesburg, periodic violent protest actions led by young people and women, the 
two sections of the community that bear the brunt of that crisis of unemployment (Vavi in Price 2012).”

It is easy to succumb to hopeless in this context, yet, that will only lead to an unconstructive whinge mentality. The challenge for people of faith is to defuse joy and happiness into the often oppressive environments of the city. The methods of discovering the city's joy range from appreciation of the city's natural, historical and cultural assets to recognition of individuals, families and communities who have made contributions to the life and wellbeing of the city. Linthicum (1991:165) suggests that the church must "delight in the city, in the people surrounding the church, and in each other in the community of faith". So the church is a critical urban asset in perpetuating joyfulness in our cities.

\section{Isaiah 65: verses 20 to 24}

Isaiah 65: 20, 22 includes reference to the quality and length of human life. Bakke (1997:83) summarizes this as: public health for children and aged, housing for all, food for all. The Interpreters Bible Dictionary (1956:155) explains that premature death was interpreted as a sign of divine displeasure and on the contrary a long life was counted as a blessing and a sign of approval from God, just like the long life of the patriarchs. Calvin (1993: 400) offers this interpretation: "Christ comes to repair our strength, and to restore and preserve our original condition". God's agenda for the city includes restoration of health and life. In Isaiah's vision "the city is to be a place of health and the church has the responsibility to work for the longevity and healthcare of its inhabitants" (Linthicum 1991:165).

In South African cities the standard of health is on an unending downward spiral. If we are to apply this aspect of the vision for renewal then the causes and stimulants of ill health should be addressed together with the inadequacy of the health system in the city. Linthicum (1991: 165) advises the church to be concerned with the stress of city life, which is a major contributor to both psychological and physical breakdown. People in cities are more prone to the symptoms of stress as the city context is fast-paced and competitive. The expression "only the strongest can survive" is apt for the context of the city. Thus the church needs to consider the weak, sick and depressed. Anxiety, depression and stress have debilitating effects on urban dwellers and on the economic productivity of the city. 
New drug resistant strains of TB have placed the health of the city inhabitant at greater risk. It would be irresponsible to ignore at this point, the premier killer HI virus. In South Africa people in cities are hardest hit as the spread of AIDS continues. In our cities there are many cemeteries that no longer have the space to bury the dead due to the high mortality rate, caused by AIDS. Verse 20 discusses infant mortality. Nationally, about 27 percent of pregnant women are living with HIV so in many South African cities babies die within a week of being born due to AIDS-related illnesses, diarrhoea, pneumonia and malnutrition (Cullinan 2013). Cullinan (2013) further explains that children who are born and live in urban areas face distinct health and injury challenges than that of rural children. She explained how the material conditions found in informal settlements increase children's exposure to injury and death.

In the context of rapid urbanisation, many children live in informal settlements, on the periphery of cities. These areas are characterised by inadequate housing, poor sanitation and high levels of unemployment and poverty (South African Cities Network 2011) conditions that increase children's risk of injury (Cullinan 2013).

A health media site in 2013 reported that $84 \%$ of South Africans get second rate healthcare ${ }^{12}$. South African Health Minister Aaron Motsoaledi explained, "The design of most healthcare systems favoured the rich and punished the poor, which threatened sub-Saharan Africa's ability to achieve the United Nations' health-related Millennium Development Goals by $2015 " 13$.

Isaiah's vision for the city is that the city will be a place of health. In our cities long lines of ailing people snake around our clinics, drive through our townships and you will likely drive into a funeral procession. South Africans attend a staggering number of funerals every year. Despite costly awareness campaigns, the urban consequences of AIDS have still resulted in lower life expectancy, and higher infant mortality. There are signs of hope with the life expectancy of South Africans having increased by a year to 59.6 (57.7 for males and 61.4 years for females) this according to Stats SA

12 See http://www.health24.com/Medical/HIV-AIDS/News/One-in-10-in-SA-HIV-positive-20130514

13 ibid 
$(2013)^{14}$. We still have a long way to go however, to reach life expectancy levels of cities such as Singapore which sits at $82.32^{15}$.

Isaiah (65. 21-22) then points attention to one of humankind's basic necessities: shelter. Housing is an essential issue in the city, as daily thousands of people flock to the cities in search of better prospects.

Just a year into South Africa's first democratic election, Dons Kritzinger (1995:213) described the "mushrooming presence" of the informal housing sector as part of the present urban scene in South Africa. He discussed how " $[t]$ he informal housing areas, whether planned or spontaneous, have evolved as the only way in which new urbanites worldwide can be received into the cities". According to Grigg (in Dons Kritzinger 1995:214) the city of Durban (where I was born and raised) is one of the cities in the world where the majority of the population live in informal residential areas. According to Du Toit (in Mangayi 2014:215) "the South African Homeless People's Federation regards informal settlement dwellers as homeless".

More recently in the South African context, Mangayi (2014:212-235) described homelessness in the context of the City of Tshwane as a social justice urgency revealing the indignity, poverty and marginalization that the homeless have to contend with. At a 2014 budget debate South African Human Settlements minister Lindiwe Sisulu (in Van Der Merwe 2014) expressed governments challenge with housing provision:

The problem, in crude terms, is that too many people are moving to South African cities, and there isn't enough land available for them.

'We are ill-equipped to deal with this rate of urbanisation.

Sadly it is the rich that seem to fair much better whatever the rate of urbanization, while the poor have to bear the burden of poor planning, apartheid legacy and dysfunctional and corrupt city management. Linthicum (1991: 167) succinctly states that the church should work for "safe" fairly distributed housing for all, "whether one is powerful or a nobody in the city whether one is rich or is poor".

14 ibid

15 See Hdr.undp.org 
In addition to a massive homelessness crisis, South African cities bear witness to a stunning gap between the rich and the poor. The Ginicoefficient according to the 2013 Human Development Report puts South Africa at 0.63 . Further to the wealth gap, unemployment, disproportionate access to education opportunities, poverty, pollution, crime and violence is the order of the day. Service delivery protests are regular occurrences and xenophobic tensions run high leading to violence against nationals of other African countries. To compound matters Black Economic Empowerment (BEE), a highly contentious form of black empowerment, was meant to begin the process of the reordering of South Africa's economy to redress the economic injustices of the past, but has done little in the way of justice. South Africa's policy of BEE is described as:

“...not simply a moral initiative to redress the wrongs of the past. It is a pragmatic growth strategy that aims to realise the country's full economic potential while helping to bring the black majority into the economic mainstream"16.

Tragically BEE has further exacerbated the wealth gap and led to a new brand of political and economic elite who are intoxicated with power, bloated with self-importance and obsessed with the accruements of office.

According to Gutiérrez (1973), “The poor and marginalized have a deeprooted conviction that no one is interested in their lives and misfortunes. The belief that being "poor" connotes not only economic deprivation but also social exclusion or marginality, severe violation of basic human rights, and public indifference to one's plight" (Massingale 2008). Gutierrez (in Cox 1990) suggests "the theologian's conversation partner is not 'the nonbeliever' but rather 'the nonperson'." It is clear that our obligatory interlocutor in the context of the city has to be the poor and the marginalized.

Verses 21-23, also describe material prosperity, security and enjoyment of the fruit of labour. People of faith in the city should advocate a just workable economy. Concerning this Linthicum (1991:169) adds;

16 See Black economic empowerment: http://www.southafrica.info/business/trends/empowerment/ bee.htm\#.VU0y00F7xag 
promotion of economic justice, control of the distribution of an economy, particular attention to the hurting of any urban society, and using the law of love as the highest code by which a city structures itself all become principles upon which economic development must be based.

The poet Wendell audaciously explained, "Rats and roaches live by competition under the law of supply and demand; it is the privilege of human beings to live under the laws of justice and mercy "17. Justice and mercy are key indicators of cities' humanity. More importantly justice and mercy signify a city that has risen above an "eye for an eye" and self-absorption, and has transcended to sharing, esteeming of the other, forgiveness and reconciliation. Omar McRoberts (2001) suggests,

Fighting against injustice through ideas and concrete acts of resistance: It means, among other things, presenting the marginalised as full humans, beloved of God and central protagonists in the divine drama of history, not as sub-humans alien to God and godliness.

Perhaps the highlight of the urban vision contained in Isaiah is verse 24 which reveals the closeness of God to the people of the city, "Before they call I will answer; while they are still speaking I will hear". This is a beautiful and endearing picture of a God who desires nearness and relationship. God not only establishes a new and just social and economic order but also seeks to be in communication, contact and closeness to the needs and cries of the people. God acts with a sense of urgency to hear and answer the people.

\section{Conclusion}

So, what grounds do we have to believe in Isaiah's urban vision? Postapartheid South African cities are a long distance from the ideal state as described in Isaiah 65. Yet the presence of this vision serves as a beacon of hope that causes us to rise above the prevailing circumstances and anticipate the renewing, recreating power of the God who has given cities a position of great significance in the divine renewal plan. What is exciting

17 http://en.wikiquote.org/wiki/Wendell_Berry 
about this plan is that we are called to rejoice in what God is creating, yet, not just rejoice, but to act with God. The same God calls us to actively seek the shalom of the city (Jeremiah 29.7). We can begin this action with the four endeavours I have outlined in this paper.

While we anticipate the full and complete renewal of the city, De Beer (2013) encourages us to partner with God in the process of accompanying urban communities from vulnerability to resilience, from victimhood to agency, from limited access to optimal access, from pathology to wellbeing, from dependency to self-reliance" thereby edging closer to the vision of a transformed city, a city of justice and hope ... the city of God.

\section{Bibliography}

Arendt, H 1958. The Human Condition. Chicago: University of Chicago Press. [Online] http://www.women-philosophers.com/Arendt.html [Accessed: 1 July 2015]

Baijnath, N and James, G 2014. Development priorities for African universities. International Journal of Development Education and Global Learning, Volume 7, Number 2, November 2015, pp 61-74. London: IOE Publishers.

Bakke, R 1981.The Urban Christian. Downers Grove: Intervarsity Press.

- 1987. Urban Christian. Downers Grove: Intervarsity Press

- 1997. A Theology as big as the City. Downers Grove: Intervarsity Press.

Berman, M 1987. Ruins and Reform: New York Yesterday and Today.

Dissent, Fall 1987, 423. [Online] http://www.philosophyandthecity.org/ [Accessed: 22 January 2016]

Bosch, D 1991. Transforming Mission: Paradigm Shifts in Theology of Mission. Maryknoll: Orbis.

Brueggemann, W (1993) Using God's resources wisely: Isaiah and urban possibility. Louisville: Westminister/John Knox Press.

Buttrick, G (ed) 1956. The Interpreter's Bible. New York: Abingdon.

Calvin, J 1993. Calvin's Commentaries. Vol. 8. Grand Rapids: Baker House. 
Cameron and Krynauw (2001:1) City Of Tshwane: Development Challenges. [Online] http://repository.up.ac.za/bitstream/handle/2263/8190/5b3. pdf?sequence $=1$ [Accessed: 22 January 2015]

Chomsky, N 1967. The Responsibility of Intellectuals. [Online] https://chomsky.info/19670223/ [Accessed: 22 January 2016]

Conn, H and Ortiz, M (2001) Urban Ministry, The Kingdom, The City and the People of God. Downers Grove: IVP.

Cullinan, K 2013. South Africa far from targets to reduce maternal, infant mortality. [Online] http://www.health-e.org.za/2013/10/29/south-africa-fartargets-reduce-maternal-infant-mortality/ [Accessed: 22 January 2016]

De Beer, S 1997. Developing community ministries. Pretoria: Institute for Urban Ministries.

- 1998. Understanding Urban Powers and Systems. Pretoria: Institute for Urban Ministries.

- 2012. Urban South Africa" An opportunity for liberating theological education. Missionalia. Vol 40, 3. [Online] http://missionalia.journals.ac.za/ pub/article/view/32/pdf_6 [Accessed: 22 January 2016]

- 2012. Urban South Africa: An opportunity for liberating theological education. Missionalia 40:3 (Nov 2012), pp 251-277.

- 2013.Community Development. Unpublished presentation.

- 2014. Whose knowledges shape our city? Advancing a communitybased urban praxis. De Jure. 47 Volume 2, pp 218-230 Pretoria: Pretoria University Law Press

De Beer, S and Swart, I 2014. Towards a fusion of horizons: Thematic contours for an urban public theological praxis-agenda in South Africa. HTS Theological Studies. Vol 70, No 3. [Online] http://www.hts. org.za/index.php/HTS/article/viewFile/2812/5236 [Accessed 22 January 2016]

Duffield, I 1997. Urban Christ. Sheffield: Urban Theological Unit.

Elshtain, J 2014. Why Public Intellectuals? [Online] http://wilsonquarterly.com/ stories/why-public-intellectuals/ [Accessed: 22 January 2016] 
Faithful capital: Cities Report. Commission on Urban Life and Faith. 2006. [Online] https://www.churchofengland.org/media/1163661/faithful\%20cities.pdf [Accessed 22 January 2016]

Furedi (2005). Where Have All the Intellectuals Gone? : Confronting $21^{\text {st }}$ Century Philistinism. London: Continuum.

Green, L 2009. Let's Do Theology. London: Continuum.

Gutierrez, G1973. A theology of liberation. Maryknoll, NY: Orbis Books. Hevesi, D. 2010. Nico Smith, Minister and Fighter of Apartheid, Dies at 81. [Online] http://www.nytimes.com/2010/06/25/world/africa/25smith.html [Accessed: 22 January 2016]

Holland, J and Henriot, P (1983) Social Analysis: Linking Faith and Justice. Maryknoll: Orbis.

Hove, $\mathrm{M}$ et al. 2013. The Urban Crisis in Sub-Saharan Africa: A Threat to Human Security and Sustainable Development. In Stability, International Journal of Security and Development. Vol 2, Issue 1. [Online] http://www.stabilityjournal.org/articles/10.5334/sta.ap/ [Accessed: 22 January 2016]

James, GL 2007. And God said "Let there be Charismatics in the City: A Study into the Practise and Presence of a Charismatic Megachurch in the City of Durban". Pietermaritzburg: UKZN.

Karecki, M 2005, 'Teaching missiology in context: Adaptations of the pastoral circle'. In Wijsen, $\mathrm{F}$ et al (ed), The pastoral circle revisited: A critical quest for truth and transformation. Nairobi: Pauline Publications. pp 159-173.

Kovacs, K (2007). Optimism vs. Hope: The Difference, Isaiah 65: 17-25 \& Luke 21: 5-19, 33rd Sunday in Ordinary Time, 18th November 2007. [Online] http://www.catonsvillepresb.org/sermons/2007/20071118.pdf [Accessed: 22 January 2016]

Khana, P 2011. When cities rule the world. [Online] http://www.mckinsey.com/ insights/urbanization/when_cities_rule_the_world [Accessed 22 January 2016]

Kritzinger, D 1995. Missiology and the Challenge of Urbanisation in South Africa. Missionalia 23:2 (August 1995), pp 201-215. 
Kritzinger, JNJ 2011. "Mission as" .. must we choose? A dialogue with Bosch, Bevans \& Schroeder and Schreiter in the South African context. Missionalia 39: 1 and 2 (April and August 2011), pp 32-59.

Latham. S Facing a failure finding a future. The London Urban Theology Project. [Online] http://www.urbantheology.org/journals/journal-2-2/editorialfacing-a-failure-finding-a-future [Accessed 20 January 2016]

Linthicum, R 1991. City of God, City of Satan. Grand Rapids: Zondervan.

Massingale, B 2008. The Scandal of Poverty "Cultured Indifference" and the Option for the Poor Post-Katrina Marquette. In Hamm, D et al (eds). University in Faithful Citizenship Principles and Strategies to Serve the Common Good Journal of Religion \& Society. Supplement Series 4. [Online] http://moses.creighton.edu/jrs/2008/2008-29.pdf [Accessed: 22 January 2015]

Mangayi, C 2014. Poverty, marginalisation and the quest for collective wellbeing in the context of homelessness in the City of Tshwane. Missionalia 42:3 (Nov 2014), pp 212-235.

Mashau, D 2014. More than just a piece of land: Power dynamics in the land discourse within the City of Tshwane. Missionalia 42:3 (Nov 2014), pp192-211.

McRoberts, O 2001. Black Churches, Community and Development. [Online] http://www.nhi.org/online/issues/115/McRoberts.html [Accessed: 22 January 2016]

Plato, Phaedrus, 230d. [Online] http://www.philosophyandthecity.org/ [Accessed: 22 January 2016]

Pre-History of Pretoria. [Online] http://www.sahistory.org.za/topic/prehistorypretoria [Accessed: 22 January 2016]

Pretoria's new street names. [Online] http://showme.co.za/pretoria/tourism/ pretorias-new-street-names/ [Accessed: 22 January 2016]

Price, C (2012). Youth unemployment: South Africa's ticking bomb. [Online] http://mg.co.za/article/2012-02-21-youth-unemployment-south-africasticking-bomb/ [Accessed: 22 January 2016] 
Saayman, W 2013. Troublemaker in Israel: Nico Smith and the struggle for justice in apartheid South Africa. NGTT Vol. 54, No. 3 \& 4, September and Desember 2013, pp 1-9.

Schreiter, R 1985. Constructing Local theologies. Maryknoll: Orbis.

Strauss, G (2005). What public intellectuals need, and why we need public intellectuals? [Online] http://www.cardus.ca/comment/article/249/what-publicintellectuals-need-and-why-we-need-public-intellectuals/

[Accessed: 22 January 2016]

Van Der Merwe, M 2014. Analysis: Africa's Cities, Crying out for Re-Imagination 29 Jul 2014 (South Africa). [Online] http://www. dailymaverick.co.za/ARTICLE/2014-07-29-ANALYSIS-AFRICAS-CITIES-CRYING-OUT-FOR-REIMAGINATION/\#.VP17MVMUD8F [Accessed: 22 January 2016]

M \& G Africa Writers. 2014. [Online] http://mgafrica.com/article/2014-09-12-factsand-figures-from-around-the-continent-that-will-leave-you-in-awe [Accessed: 22 January 2016]

What is theology? [Online] http://www.theguardian.com/commentisfree/belief/2010/ may/24/religion-philosophy [Accessed: 22 January 2016]

Wirth, L 1938. Urbanism as a Way of Life. In LeGates TR and Stout F (ed). The City Reader. London and New York: Routledge. pp 189-197.

http://www.merriam-webster.com/dictionary/philistine

http://www.health24.com/Medical/HIV-AIDS/News/One-in-10-in-SA-HIV-positive-20130514

Hdr.undp.org

http://www.southafrica.info/business/trends/empowerment/bee.htm\#.VU0y00F7xag http://en.wikiquote.org/wiki/Wendell_Berry 